\title{
The Effect of Substitution of Mungabean Flour and Tapioca on the Acceptability of Pie Shells as a Source of Fiber and Potassium
}

\author{
$1^{\text {st }}$ Yuli Hartati \\ Department of Nutrition \\ Poltekkes Kemenkes Palembang \\ Palembang, Indonesia \\ umi_yuli@yahoo.com
}

\author{
$2^{\text {nd }}$ Risma Royanda \\ Department of Nutrition \\ Poltekkes Kemenkes Palembang \\ Palembang, Indonesia \\ risma.royanda30@gmail.com
}

Corresponding author: umi_yuli@yahoo.com

\begin{abstract}
Pie is a type of pastry product consisting of pie shells and toppings. Pies are usually consumed as snacks among children, adolescents and adults. Creations in the processing of pie shells is rarely, most of food products, especially snacks have a low fiber and potassium content, but are high in sodium and saturated fat. Therefore, one of the creations of processing pie shells can be done by substituting the basic ingredients of making pie shells that utilize local food ingredients. The choice of mung beans in this substitution is due to the high fiber and potassium content of mung beans which can be used to reduce blood pressure in someone with hypertension.This study research determine of the best formulation, determine of the acceptability, determine of the content of macro nutrients based on proximate analysis, determine of the fiber levels, potassium levels and sodium levels in the pie shells substitution of mung beans and tapioca flour.This study research is an experimental research with non factorial complete randomized design, an experiment that is used homogeneously or there are no other factors that affect the response outside the factors studied. The results showed that there were four pie shells formulations, the best pie shelss formulations based on the acceptability test were found in F2 (75 grams of tapioca flour with 125 grams of mung bean flour). The content of macro nutrients from the best pie shells formulation are energy of 457.17 Kcal, protein $10.7 \%$, fat $18.73 \%$, and carbohydrates $61.45 \%$. While the level of food fiber $13.18 \%$, sodium levels $106.47 \mathrm{mg}$ and potassium levels $568.02 \mathrm{mg}$ per 100 grams of pie shells.Need to increase carbohydrate content of pie shells (in the filling) by choosing the right food ingredients and pay attention to the sodium content of these foods. Further research needs to be done on the acceptability of pie shells with the addition of filling. And regarding the effect of giving pie shells substitution of mung bean flour and tapioca as a source of fiber and potassium to decrease blood pressure in hypertensive patients.
\end{abstract}

Keywords: Formulation pie shells, mung bean, fiber, pottasium and natrium.

\section{INTRODUCTION}

The 2018 Food Consumption Statistics based on the National Socio-Economic Survey shows that the consumption of pastries per capita per year in Indonesia is 22,824 ounces with an average growth from $2014-2018$ of $33.31 \%$. When viewed from the Food Consumption Figures by the Food and Drug Supervisory Agency (BPOM) in 2018, the figure for pie type food consumption in Indonesia is $30 \mathrm{~g} /$ person / day. Patiseri" is a form of knowledge in the processing and presentation of food, especially in processing and serving various types of cakes. Patiseri comes from French, namely "Pậtisserie" which means pastries. Thus, patiseri can be interpreted as a science that studies the ins and outs of cakes. Patiseri is divided into two, namely oriental pastries and continental pastries. Indonesian pastries are an oriental type of cake, while what includes continental cakes are, Yeast Products, Breads, Cake and Icings, Cookies, Pastries, Cream, Pudding, Frozen Dessert, Candy [1].

Pastries, another type of dough from pastry known as a paste, is made from a mixture of flour, liquid and fat. In practice, pastry refers to two groups of dough, namely dough and batters, hard dough and soft dough, and many other derivative products. The hard dough group consists of Puff Pastry, Danish and Croissant, Strudel, Short Paste. While the soft dough group consists of Choux paste. Short pastry is the simplest type of pastry. Short pastry products in Indonesia are known as "pie" products which are served with the addition of custard flour and fruit slices on top [1]. 
Pie is a type of pastry product consisting of pie shells and toppings, usually in the form of sheets, rounds, bowls, lotus flowers and so on. Pie skin is one of the pastry products with the characteristics of crunchy, dry and savory. The basic ingredients for making pie crusts are wheat flour, butter, eggs and salt [2]. Pie is usually consumed as a snack or a snack among children, adolescents and adults. At this time the types of food varied. The presence of patiseri products contributes to the type of food available in the community. However, there are still few creations in the processing of pie crusts, so it is necessary to do creations in the processing of pie crusts, one of which can be done by substituting the basic ingredients for making pie crusts by utilizing local food ingredients.

One of the local foods that can be used as a substitute for tapioca flour is green beans which have been made into flour first. The choice of green beans as a substitute for tapioca flour is due to the high fiber and potassium content of green beans that can be used to reduce blood pressure in someone with hypertension. Because currently most food products, especially snacks or snacks, contain low fiber and potassium, but high levels of sodium and saturated fat. So that if consumed continuously it will be bad for the body. Research on green beans has been done a lot, including [3] about making cookies for green bean flour substitution of weevil flour, [4] about steamed sponge substitution of mung bean flour as well as [5] about the quality of the pie crust of green bean flour substitution.

Hypertension or high blood pressure is an increase in systolic blood pressure of more than $140 \mathrm{mmHg}$ and diastolic blood pressure of more than $90 \mathrm{mmHg}$ on two measurements with an interval of five minutes in a state of sufficient rest / calm. Hypertension is a degenerative disease that is a serious public health problem, because if it is not controlled it will cause dangerous complications [6]. Riskesdas 2018 [7] shows the prevalence of Non-Communicable Diseases (PTM) has increased when compared to Riskesdas 2013, one of which is hypertension. The prevalence of hypertension in Indonesia, from the results of blood pressure measurements, increased from $25.8 \%$ in 2013 to $34.1 \%$ in 2018 .

In South Sumatra Province alone in 2018 the prevalence of hypertension was $30.44 \%$. Whereas in Palembang City itself in early 2017, namely in January, hypertension was included in the 10 largest diseases in Palembang City and was ranked second, the prevalence of hypertension in Palembang City based on measurements in 2017 was 23\%. (Riskesdas 2018 and Health Office Palembang 2017) [7]. In controlling hypertension, it can be done by complying with the five stages of controlling hypertension. Diet is one of the important things in the five stages, this management is difficult to succeed because the patient does not pay attention to the intake of food consumed. Among the recommended food intake are foods rich in fiber and high in potassium. One of the foods that can meet these nutritional needs is green beans. Mung beans are a type of cultivated plant and palawijaya that have many benefits in everyday life as a source of high protein vegetable food. Mung beans have a fairly high protein content of $22 \%$ and are an important source of minerals, including calcium, phosphorus, and potassium. In addition, green beans also have a fairly high fiber content, which is around 7.6g / 100g [4].

\section{METHODS}

\section{A. Tools and Materials}

The tools used to make pie crusts: dough basins, forks, tablespoons, pans, pie molds, digital scales, measuring cups, bowls, sieves, pans, stirring silk and oven. The instrument for the acceptance test is an organoleptic test form which is given to the panelists who have passed the selection. Chemical testing tools are equipment in proximate analysis tests at PT. Saraswati Indo Genetech. The ingredients used in the process of making pyramid skin include: tapioca flour, green bean flour, palm oil, refined sugar, salt and ice water.

\section{B. Place of Research}

The determination of the formulation and manufacture of pie crusts and the acceptance test will be carried out at the Food Technology Science Laboratory of the Nutrition Department of the Health Polytechnic of the Ministry of Health in Palembang and for proximate analysis at PT. Saraswati Indo Genetech. This research was conducted in January 2020.

\section{Research Stages}

\section{Making Mung Bean Flour}

The mung beans that have been prepared are sorted first, selected and separated from the impurities, then washed thoroughly. After washing the mung beans, let them stand and dry in the sun until all parts dry. Furthermore, if the mung beans are dry, you can do the grinding or flouring process using a blender or flour machine. After becoming flour, the sieving process is carried out with 2 times, namely the coarse sieve and the fine sieve.

2. Determination of Pie Shells Formulation

The materials used in the process of making pyramid skin include:

a. Mung Bean Flour

b. Tapioca flour

c. Additional ingredients used are palm oil, egg yolk, refined sugar, salt and ice water 


\section{Pie Shells Making}

The process of making this pie crust begins with mixing the ingredients, which consists of tapioca flour, green bean flour, palm oil, egg yolk, powdered sugar and salt then stirred by rubbing in the method until it is mixed and forms a sand dough, after that a little ice water is added. little by little until the dough is lumpy. If the dough is homogeneous, the next process is printing. Dough printing is done by rolling the homogeneous dough then rolling it or flattening it and then molding it into a small pie mold and stabbing it with a fork so that the skin does not puff up when baked. Next, arrange them on a baking sheet and then

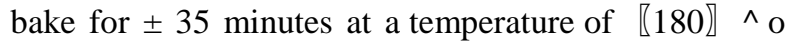
$\mathrm{C}[2]$.

4. Acceptability Test

The consumer's preference for pie shells products with various formulas of mung beans flour and tapioca flourrated through the senses of eyesight, taste, touch, smell. Includes color, aroma, texture and taste.

\section{Proximate Analysis}

These laboratory tests include proximate analysis, fiber content analysis, analysis of potassium and sodium levels which are carried out at the PT. Saraswati Indo Genetech. The results of the proximate test analysis are energy, protein, fat, ash content, moisture content and total carbohydrate. The results of the fiber content analysis were obtained by means of the enzymaticgravimetric fiber content test by the Association of Official Analytical Chemist (AOAC) method. Analysis of potassium levels was obtained by means of testing potassium levels with the Atomic Absorption Spectrophotometry (AAS) method. While the analysis of sodium levels is obtained by testing the sodium content of the Selective Ion Electrode method.

\section{RESULTS AND DISCUSSION}

The pie crust formulation of the substitution of mung bean flour and tapioca that has been made is then carried out an organoleptic test to see its acceptability. Organoleptic test or sensory analysis of a product which includes color, taste, aroma, texture.

Organoleptic tests were carried out using a score scale of 1 - 5 with categories of very dislike, dislike, somewhat like, like, very like. Organoleptic tests were carried out on the four formulations of pie crusts substituting green bean flour and tapioca, namely F1, F2, F3 and F4.

The hedonic test results showed that the most preferred formulation was the F2 formula and the least preferred formulation was the $\mathrm{F} 4$ formula.
Table 1. Organoleptic Test Results Based on Color Criteria

\begin{tabular}{|c|c|c|c|c|c|c|c|c|}
\hline \multirow{2}{*}{$\begin{array}{l}\text { Color } \\
\text { Criteria }\end{array}$} & \multicolumn{2}{|c|}{ Fl } & \multicolumn{2}{|c|}{ F2 } & \multicolumn{2}{|c|}{ F3 } & \multicolumn{2}{|c|}{ F4 } \\
\hline & n & $\%$ & $\mathbf{n}$ & $\%$ & $\mathbf{n}$ & $\%$ & $\mathbf{n}$ & $\%$ \\
\hline $\begin{array}{l}\text { Really } \\
\text { Lika }\end{array}$ & 2 & 6.7 & 9 & 30,0 & 5 & 16,7 & 0 & 0 \\
\hline Like & 13 & 43.3 & 15 & 50,0 & 16 & 53,3 & 4 & 13,3 \\
\hline $\begin{array}{l}\text { Rather } \\
\text { Like }\end{array}$ & 12 & 40,0 & 5 & 16,7 & 9 & 30,0 & 9 & 30,0 \\
\hline $\begin{array}{l}\text { Do Not } \\
\text { Like }\end{array}$ & - & 6,7 & 1 & 3,3 & 0 & 0 & 16 & 53,3 \\
\hline $\begin{array}{l}\text { Vey } \\
\text { Dislike }\end{array}$ & 1 & 3,3 & 0 & 0 & 0 & 0 & 1 & 3,3 \\
\hline
\end{tabular}

Based on Table 1, it can be seen from the total score of the four formulas in the organoleptic test on color, the pie crust which has the highest total percentage is $53.3 \%$ with the like criteria in the F3 formula, while the pie crust which has the lowest total percentage is $3.3 \%$ with the criteria dislike the F2 formula. This shows that most of the panelists prefer the pie skin color in the F3 formula compared to the F1, F2 and F4 formulas.

The resulting color on the skin of the F1, F2, F3 and F4 pieformulas has a brownish yellow color. This pie crust is a mixture of green bean flour and tapioca flour, so the final product is brownish green in color. Color can be caused due to the caramelization process and the effect of drying first [8]. The color equation occurs due to the roasting process. Naturally, the color is damaged by heating. Chemically, oxidation changes during storage. The result is processed food loses color and can reduce sensory values [9].

In $\mathrm{F} 1$ formula pie crust, the resulting color is brownish yellow, this is because the ratio of flour used is $50 \%$ : $50 \%$. The F2 formula produces a greenish yellow color and is slightly pale due to the addition of more mung bean flour. On the pie crust, the F3 formula produces a yellow green-brown color, the same as the F4 formula but is slightly darker and darker. In this case, the F3 and F4 formulas have a much different color difference, due to the composition of the ingredients, namely green bean flour which is greater than tapioca flour, resulting in a darker brownish green color. In the oven process, you also need to pay attention to how long it takes the longer the pie crust is baked, the darker the pie crust will be.

This research is in line with the research of Hearsa and Elida (2019) [5], which explains that the color quality results have a different effect on the color of the pie crust with different substitutions for green bean flour. 
The color of the green bean pie crust is influenced by the use of mung bean flour compared to other ingredients. The use of more and more mung bean flour measures, the results of the pie crust will get darker yellow green brown. The protein content in green bean flour allows the pie crust to change color. According to Handayani and Elida (2018) [10] "The longer the roasting takes, the resulting product is getting brown because of the browning reaction".

Table 2. Organoleptic Test Results Based on Aroma Criteria

\begin{tabular}{lccccccccc}
\hline & \multicolumn{2}{c}{ F1 } & \multicolumn{2}{c}{ F2 } & \multicolumn{2}{c}{ F3 } & \multicolumn{2}{c}{ F4 } \\
\cline { 2 - 9 } Aroma & $\mathbf{n}$ & $\%$ & $\mathbf{n}$ & $\%$ & $\mathbf{n}$ & $\%$ & $\mathbf{n}$ & $\%$ \\
Really Like & 2 & 6,7 & 4 & 13,3 & 4 & 13,3 & 3 & 10,0 \\
\hline Like & 18 & 60,2 & 15 & 50,0 & 14 & 46,7 & 8 & 26,7 \\
\hline Rather Like & 8 & $26 / 2$ & 9 & 30,0 & 7 & 22,3 & 15 & 50,0 \\
\hline $\begin{array}{l}\text { Do Not } \\
\text { Like }\end{array}$ & 2 & $6 / 2$ & 2 & 6,7 & 5 & 16,7 & 4 & 13,3 \\
\hline $\begin{array}{l}\text { Very } \\
\text { Dislike }\end{array}$ & 0 & 0 & 0 & 0 & 0 & 0 & 0 & 0 \\
\hline
\end{tabular}

Based on Table 2, it can bee seen from the total score of the four formulas in the organoleptic test on aroma, the pie crust has the highest total percentage of $60 \%$ with the criteria for liking the $\mathrm{F} 1$ formula, while the pie crust which has the lowest total percentage is $6.7 \%$ with the criteria of dislike on the F1 and F2 formulas. This shows that most of the panelists prefer the aroma of pie crust in the F1 formula compared to the F2, F3 and F4 formulas. There is no significant difference from the aroma of the four pie crust formulas. This is because the basic ingredients in the manufacture of pie crusts are tapioca flour and green bean flour, the amounts of which do not differ much between treatments. The distinctive aroma that is generated is more influenced by the green bean flour.

In the research of Hearsa and Elida (2019) [5], it was also explained that the results of the quality of the aroma of the pie crust had a different effect on the fragrant aroma of the pie crust. The aroma produced in making pie crusts is due to the basic ingredients of margarine and the use of green bean flour. According to Khoirunisa (2016) [2], pie skin has a distinctive aroma because it has constituent ingredients such as wheat flour, eggs and fat.Aroma is an odor that is difficult to measure, so it usually leads to different opinions in assessing the quality of the aroma. Differences in opinion can be caused by each person having different smells, although they can distinguish between scents, everyone has different preferences [11].
Tabel 3.

Organoleptic Test Results Based on Taste Criteria

\begin{tabular}{|c|c|c|c|c|c|c|c|c|}
\hline \multirow{2}{*}{$\underset{\text { Criteria }}{\text { Aroma }}$} & \multicolumn{2}{|c|}{ FJ } & \multicolumn{2}{|c|}{$\mathbf{F} 2$} & \multicolumn{2}{|c|}{$\mathbf{r 3}$} & \multicolumn{2}{|c|}{$\mathbf{r 4}$} \\
\hline & $\mathbf{N}$ & $\%$ & $\mathbf{n}$ & $\%$ & $\mathbf{n}$ & $\%$ & $\mathbf{n}$ & $\%$ \\
\hline Very Like & 2 & 6,7 & 5 & 16,7 & 3 & 10,0 & 2 & 6,7 \\
\hline Like & 15 & 50,0 & 7 & 23,3 & 10 & 33,3 & 10 & 33;: \\
\hline Rather Like & 8 & 26,7 & 14 & 46,7 & 10 & 33,3 & 9 & 30,1 \\
\hline Do Not Like & 5 & 16,7 & 4 & 13,3 & 7 & 23,3 & 8 & 26,7 \\
\hline Very Dislike & 0 & 0 & 0 & 0 & 0 & 0 & 1 & 3,3 \\
\hline
\end{tabular}

Based on Table 3, it can be seen from the total score of the four formulas in the organoleptic test on texture, the pie crust which has the highest total percentage is $60 \%$ with the like criteria in the F1 formula, while the pie crust which has the lowest total percentage is $3.3 \%$ with the dislike criteria. on the formula F2. This shows that most of the panelists prefer the texture of the F1 formula compared to the F2, F3 and F4 formulas. Food texture is an assessment factor that is determined through the sense of touch and or by touch by measuring the hardness or consistency of food products. Food texture is determined by water content, fat content, carbohydrates and protein. The greater the protein content, the greater the water absorption. Mung bean flour is a high source of protein compared to other ingredients, which increases water absorption so that the resulting pie crust is sturdier. It is proven that the pie crust formulations F3 and F4 use more green bean flour than F1 and F2, so the resulting texture is harder. F1 pie skin with the same ratio of green bean flour and tapioca flour to produce a crunchy texture. Meanwhile, F2 with a ratio of more green bean flour, resulting in a firmer and crunchy texture.

Tabel 4.

Organoleptic Test Results Based on Texture Criteria

\begin{tabular}{lcccccccc}
\multicolumn{1}{c}{ Organoleptic Test Results Based on Texture Criteria } \\
\hline $\begin{array}{l}\text { Texture } \\
\text { Criteria }\end{array}$ & \multicolumn{2}{c}{ F1 } & \multicolumn{2}{c}{ F2 } & & F: & \multicolumn{2}{c}{ F4 } \\
\cline { 2 - 9 } & $\mathbf{n}$ & $\%$ & $\mathbf{n}$ & $\%$ & $\mathbf{n}$ & $\%$ & $\mathbf{n}$ & $\%$ \\
\hline Very Like & 6 & 20,0 & 6 & 20,0 & 3 & 10,0 & 2 & 6,7 \\
\hline Like & 18 & 50,0 & 15 & 50,0 & 17 & 56,7 & 15 & 50,0 \\
\hline $\begin{array}{l}\text { Rather } \\
\text { Like }\end{array}$ & 3 & 10,0 & 8 & 26,7 & 7 & 23,3 & 10 & 33,3 \\
\hline $\begin{array}{l}\text { Do } \\
\text { Like }\end{array}$ & 2 & 6,7 & 1 & 3,3 & 3 & 10,0 & 3 & 10,0 \\
\hline $\begin{array}{l}\text { Very } \\
\text { Dislike }\end{array}$ & 1 & 3,3 & 0 & 0 & 0 & 0 & 0 & 0 \\
\hline
\end{tabular}


Based on Table 4, it can be seen from the total score of the four formulas in the organoleptic test on taste, the pie crust has the highest total percentage of $50 \%$ with the criteria for liking the F1 formula, while the pie crust which has the lowest total percentage is $3.3 \%$ with very poor criteria. like the formula F4. This shows that most of the panelists prefer the taste of the pie crust in the F1 formula compared to the F2, F3 and F4 formulas.

The taste of the four pie crust treatments is more influenced by the use of the basic ingredients of green bean flour, and there is also the influence of additional ingredients such as sugar and a little salt. This is in line with the research of Hearsa and Elida (2019) [5] which explains that the results of the savory taste quality of the pie crust have no difference effect on the taste of the pie crust. The savory taste of the pie crust is caused by the use of salt and the use of green bean flour in the processing of the pie crust. According to Annisa Ulkhair (2018) [5], the taste of food is the second factor that determines the taste of food after its appearance.

The taste of food is an assessment factor for the results of combining the formulation of ingredients in making a food product that is assessed by the tongue, by measuring sweet, sour, salty, bitter, or other combinations, and is a determinant of the level of preference for food products. The resulting solid food taste is sweet and savory. Sugar contributes to the sweetness and tenderness of the product [12].

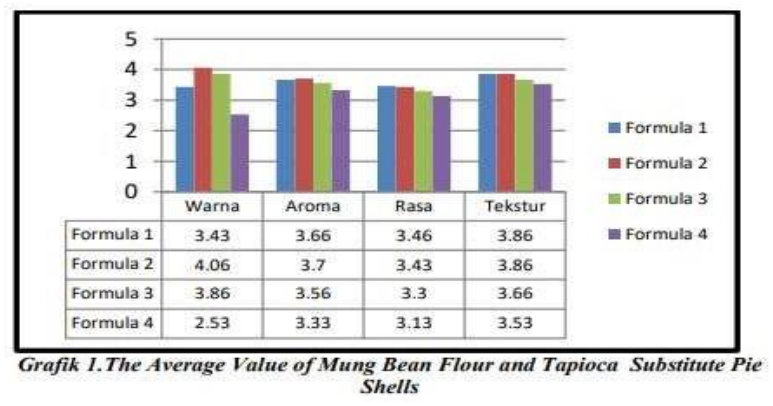

Graph 1 shows that the type of formula most favored by the panelists from all aspects of the assessment is F2 with the use of 75 grams of tapioca flour and 125 grams of mung bean flour. These results indicate that the addition of mung bean flour that can still be accepted by the panelists is in the second formulation (F2), while for the use of green bean flour which is more than the two formulas F1 and F2, namely in F3 and F4 there are still some panelists who do not like it. This can be seen from the assessment of color, taste, aroma and texture by the panelists.

In determining the best formulation, the data displayed in the organoleptic test results in the table with the data displayed on the graph is different because the data displayed in the organoleptic test results in the table only sees the highest percentage of the four formulations, where the percentage only describes the number of panelists in one. one hedonic scale (really likes / likes / likes / dislikes / really dislikes) not from the calculation of the score given by the panelists, so that the organoleptic test results of this table cannot be used as a benchmark for determining the best formulation because the highest percentage changes . Whereas the data displayed on the graph is the result of the accumulated value given by the panelists based on the hedonic scale score which is then averaged, so that the results obtained are more likely to be used as a benchmark for determining the best formulation. Where of the four criteria F2 is the most superior compared to $\mathrm{F} 1, \mathrm{~F} 3$ and F4.

Tabel 5.

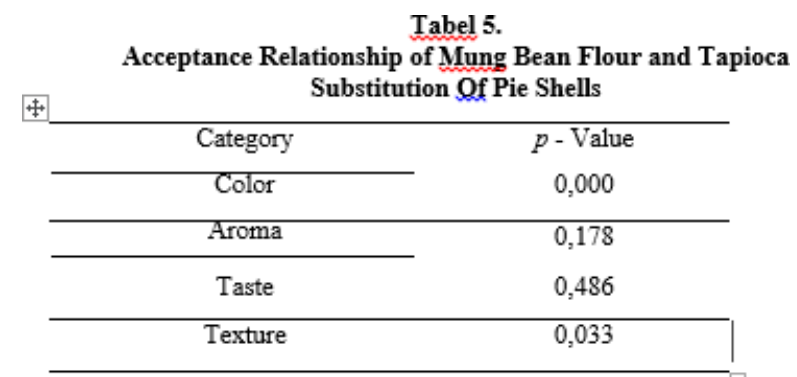

Based on Table 5, it is explained that there is a relationship between the acceptability of pie crusts with the substitution of green bean flour and tapioca in terms of color and texture $(p<0.05)$, while in terms of aroma and taste there is no relationship between acceptance of pie crusts and substitution of mung bean flour. and tapioca ( $p>0.05)$. The relationship between the acceptance of pie crust and the substitution of mung bean flour and tapioca was analyzed using the Friedman Test statistical test.

\section{Proximate Analysis}

Proximate analysis was carried out to determine the composition of macro nutrients from the best treatment results of the substitution pie crust of green bean flour and tapioca, namely the F2 formulation with 75 grams of tapioca and 125 grams of mung bean flour. The chemical analysis has benefits as an assessment of the quality of food, especially on the nutritional standards that should be contained in the pie crust.

The chemical analysis carried out included examination of the content of macro nutrients (levels of protein, fat, carbohydrates), potassium, sodium and dietary fiber. The results of the study on the nutritional content of the pie crust of green bean flour and tapioca substitution are as shown in Table 6: 
Tabel 6.

Proximate Analysis of Mung Bean Flour and Tapioca Substitution of Pie Shells

\begin{tabular}{lcc}
\hline \multicolumn{1}{c}{ Parameter } & Unit & Result \\
\hline Total Energy & Kkal & 457,17 \\
\hline Protein & $\%$ & 10,70 \\
\hline Total fat & $\%$ & 18,73 \\
\hline Carbohydrate & $\%$ & 61,45 \\
\hline Water content & $\%$ & 7,36 \\
\hline Ash content & $\%$ & 1,76 \\
\hline Sodium & $\mathrm{Mg}$ & 106,47 \\
\hline Potassium & $\mathrm{Mg}$ & 568,02 \\
\hline Fiber & $\%$ & 13,18 \\
\hline
\end{tabular}

Tabel 7.

Comparison of Nutritional Substances of Mung Bean Flour and Tapioca Substitution of Pie Shells with SNI (SNI.01.2973.1992)

\begin{tabular}{lcc}
\hline Parameter & $\begin{array}{c}\text { Kulit Pie Subsitutsi Tepung } \\
\text { Kacang Hijau dan Tapioka } \\
\mathbf{( \% )}\end{array}$ & $\begin{array}{c}\text { SNI Mutu } \\
\text { Kulit Pie } \\
\mathbf{( \% )}\end{array}$ \\
\hline Protein & 10,70 & Maks. 6,5 \\
\hline Fat & 18,73 & Min. 18 \\
\hline Carbohydrate & 61,45 & Min. 70 \\
\hline Water content & 7,36 & Maks. 5,0 \\
\hline Ash content & 1,76 & Malss. 1,5 \\
\hline
\end{tabular}

Protein Content. In food ingredients, it is a source of amino acids that contain elements of $\mathrm{C}, \mathrm{H}, \mathrm{O}$ and $\mathrm{N}$ which are not owned by fats and carbohydrates. Protein is a very important nutrient for the body, because in addition to its function as an energy producer, a building block and a regulatory substance [13].

The protein content contained in the Peanut and Tapioca Substitution Pie Skins is $10.7 \%$. The results of the proximate analysis showed that the protein content in the pie crust was $4.2 \%$ higher than the SNI for the quality of the pie crust, this could be due to the choice of a substitute material, namely mung bean flour, because green beans themselves have a high protein nutrient content, which is $22 \%$.

The results of this study indicate that the protein in green beans has an effect on the addition of nutrition to the pie crust. This research is also in line with research [4] which states that there is an effect of added green bean flour substitution, the more green bean flour is added, the more protein content in the resulting product, namely steamed cake. This is also in accordance with the reference obtained that the more the addition of green bean flour, the more protein content in a product increases, because the high protein content contained in green bean flour is $19.09 \%$ per 100 grams [14].

Meanwhile, tapioca flour itself contributes less protein nutrients, because 100 grams of tapioca flour only has
1.1 grams of protein. This is in line with Islamic research (2017) on biscuits that are substituted for tapioca flour and breadfruit flour, where in this study it can be seen that the higher the addition of tapioca flour to biscuits, the lower the protein content. Protein is a food substance that is very important for the body, because besides functioning as fuel in the body it also functions as a building and regulatory substance.

Fat level. Peanut and Tapioca Flour Substitute Pie Skins has a fat content of $18.73 \%$. This shows that the results of the proximate analysis meet the SNI requirements for the quality of pie crusts, namely at least $18 \%$

The fat content in the pie crust is obtained from the composition of the pie crust formulations which still have a high fat content. The source of fat in the piebera shell comes from palm oil and egg yolks. If it is directed to low-fat healthy food products, it is necessary to look for a better composition of constituents with the same functionality and a lower fat content.

Quoted from research by Rasmaniar et al (2017) [15], it is stated that fat is the most important raw material in making pastries. The more fat you add to the dough, the more brittle the cookies will be. In the body fat functions primarily as an energy reserve in the form of fat tissue. Fats and oils are found in almost all food ingredients with different contents.

In Ratnasari's (2015) research on biscuits substituting for pumpkin flour and mung bean flour, the fat content of biscuits tends to increase along with the increasing proportion of pumpkin flour and the less proportion of adding mung bean flour and the addition of margarine. Because from the results of the analysis of the fat content of mung bean flour, the fat content was $0.09 \%$ and the tapioca flour was $0.5 \%$, while the higher the addition of margarine or oil, the fat content increased [14].

Carbohydrate levels. The results of the analysis of carbohydrate content in the Peanut and Tapioca Substitute Pie Skins were $61.45 \%$. These results indicate that the carbohydrate content of the pie crust has not met the SNI quality requirements, namely $70 \%$. Based on the research of Erlinawati et al (2014) [16] regarding the carbohydrate content in purple sweet potato flour cookies, green bean flour substitution, it is stated that the highest carbohydrate content is in sweet potato cookies with $30 \%$ green bean flour substitution, which is $63.28 \%$ while the lowest is in cookies without substitution of green bean flour, namely $58.42 \%$. It can be said that there is an influence on the carbohydrate content of the pie crusts and purple sweet potato flour 
cookies that have been substituted with green bean flour. The carbohydrate content in the resulting pie crust is influenced by the carbohydrate content in the raw material where the carbohydrate content in green bean flour is $72.86 \%$ while the carbohydrate content in tapioca flour is $88.2 \%$. Carbohydrates are a source of energy for the body besides carbohydrates also have an important role in determining the characteristics of food ingredients such as taste, color and texture [13].

Energy Content. The content value is obtained based on the calculation of the conversion of protein, fat, and carbohydrate content into Calorie units. The biggest source of energy production is fat. Conversion 1 gram of fat is 9 Calories. carbohydrates and protein which is 1 gram is equivalent to 4 calories. The energy content of the Peanut and Tapioca Flour Substitute Pie Shells is 457.17 Kcal per 100 grams of pie crust. The energy content meets SNI standards for pie crust, which is a minimum of $400 \mathrm{Kcal}$ per 100 grams. As for energy, 1 piece of pie crust without content weighing 25 grams is 114 Kcal.

Calorie is a unit equivalent to heat. Each food ingredient has different caloric values which are not the same [12]. Fiber Levels. The results of the analysis of the levels of dietary fiber on the skin of Pie Substituted Mung Beans and Tapioca are $13.18 \%$ per 100 grams In controlling hypertension, fiber sources such as fruits and vegetables are also needed. In the Daily Nutrient Goals used in the DASH study, the recommended daily fiber requirement is 30 grams / day [17]. In this study, the substitution of green bean flour and tapioca pie crust products contributed $44 \%$ of the fiber requirement for the body.

In a study by Erlinawati et al. (2014) [16], regarding the fiber content in cookies of purple sweet potato flour with the substitution of green bean flour, it was explained that the fiber content of cookies after being substituted for mung bean flour had increased compared to before being substituted. This increase in fiber content can be caused by the fiber content in 100 grams of green beans by 7.5 grams.

Sodium levels. The results of the analysis of sodium levels in the skin of the Pie of Substitution Green Pea Flour and Tapioca were $106.47 \mathrm{mg}$ per 100 grams. In handling hypertension with the DASH diet method or Dietary Approaches to Stop Hypertension, several types of food ingredients are recommended and limited. One of the food ingredients that must be limited is food ingredients that contain high sodium levels. According to the modified table of Dietary Approaches to Stop Hypertension (DASH) part 3, limiting the consumption of table salt for the daily portion is not more than 1 teaspoon or the equivalent of 1000-1200 mg of sodium [7]. In this study, a pie crust product substituted for mung bean flour and tapioca contributed $8.9 \%$ of sodium to the body.

Potassium levels. The results of the analysis of potassium levels in the skin of Pie Substituted Mung Beans and Tapioca are $568.02 \mathrm{mg}$ per 100 grams. In the DASH diet there are also recommended food ingredients including food sources of potassium and fiber, which are included in food sources of potassium which are fresh fruits, vegetables and nuts. Following the DAHS diet plan, the recommended daily serving of fruit and vegetables is 4-5 servings per day, while nuts are 4-5 servings per week, in other words the need for potassium for hypertensive sufferers is $3500-4500 \mathrm{mg}$ per day [17]. In this study, a pie skin product substituted for mung bean flour and tapioca contributed $12.6 \%$ of potassium to the body.

Water content. The results of the analysis of the moisture content of the Pie Skins with the Substitution of Mung Beans and Tapioca were $7.36 \%$ per 100 grams. If it is seen from the specifications of the quality requirements of SNI 01-2973-1992 which has a maximum water content of $5.0 \%$, the moisture content of the pie crusts of the substitution of green bean flour and tapioca produced from this study exceeds the requirements of the SNI quality standard.

This high water content is due to the composition of the constituent ingredients using vegetable oil and also the addition of water. In addition, the baking process through an oven with a high temperature of $180 \mathrm{oC}$ also affects the moisture content in the pie crust. The proportion of tapioca flour also affects the moisture content of the pie crust. In the F2 formula the use of 75 grams of tapioca flour with a carbohydrate content of 66.15 grams and in Rahman's research (2007) [18] the starch content in tapioca flour ranged from $72-81 \%$ BW. The decrease in water content occurs due to the mechanism of starch and protein, causing water to no longer be bound to the maximum. The hydrogen bonds formed between starch molecules and water will be reduced by the interaction between starch and protein [14]. Ash content. The results of the analysis of the ash content in the skin of the Pie of Substitution Green Pea Flour and Tapioca were $1.76 \%$ per 100 grams. The analysis shows that the ash content in the pie crust of the substitution of mung bean flour and tapioca exceeds the quality standard requirements of SNI 01$2973-1992$, which is a maximum of $1.5 \%$.

The increase in ash content can be caused by the use of a higher proportion of mung bean flour. Ash is a mineral element or inorganic substance contained in food ingredients. Ash is also a substance in food other than water and organic matter. In addition, the ash content is also a mineral element as residue left after the material is burned until it is free of carbon 
elements, is a non- volatile component, and remains in the combustion and annealing of organic compounds [14].

Tabel 8.

Comparison of Nutritional Substances of Mung Bean Flour dan Tapioca Substitution of Pie Shells with the Calculation of TKPI per 100 grams

\begin{tabular}{lcc} 
Parameter & $\begin{array}{c}\text { Kulit Pie Substitusi } \\
\text { Tapioka dan Tepung } \\
\text { Kacang Hijau }\end{array}$ & $\begin{array}{c}\text { Perhitungan } \\
\text { TKPI }\end{array}$ \\
\hline Energy (Kcal) & 457,17 & 538 \\
\hline Protein (gram) & 10,70 & 5,1 \\
\hline Fat (gram) & 18,73 & 39,5 \\
\hline $\begin{array}{l}\text { Carbohydrates } \\
\text { (grams) }\end{array}$ & 61,45 & 43,35 \\
\hline
\end{tabular}

From Table 8 it shows that the Peanut and Tapioca Flour Substitute Pie Skins have a high protein and carbohydrate content, presumably because the basic ingredients for making this pie crust are green bean flour and tapioca Meanwhile, the energy and fat content in the pie crust is smaller than the TKPI calculation.

\section{CONCLUSION}

From the results of the study, it was concluded that there were 4 best formulations consisting of F1, F2, F3, and F4. Meanwhile, according to the results of the accumulated average assessment of the organoleptic test of the pie crust that has the best acceptance is F2 (75 grams of tapioca flour with 125 grams of mung bean flour).

The results of the proximate analysis in seeing the macro nutrient content of the best skin formulation were $457.17 \mathrm{Kcal}$ of energy, $10.7 \%$ protein, $18.73 \%$ fat, and $61.45 \%$ carbohydrates. Meanwhile, for chemical analysis, the levels of dietary fiber were $13.18 \%$, sodium levels were $106.47 \mathrm{mg}$ and potassium levels were $568.02 \mathrm{mg}$ per 100 grams of pie crust. From the results of the analysis, the energy and fat content met the standards in SNI.01.2973.1992, the protein content exceeded the quality standard, while the carbohydrate content was still less than the standard.

\section{REFERENCES}

[1] Paryono. Transferable Skills In Technical And Vocational Education And Training (TVET) In Brunei Darussalam. TVET@Asia 2014:1-15.

[2] Khoirunnisa R. EKSPERIMEN PEMBUATAN KULIT PIE SUBTITUSI RUMPUT LAUT (Eucheuma Cottonii). 2016.

[3] Nurcahyani R. The Experiment Of Making Mung Bean Flour Cookies With Banana Weevil Substitution. 2006.

[4] Dyah Ayu Kusuma W. Effect Of Mung Beans (Vigna Radiata L.) Flour Substitution On Protein Content And Acceptability Of
Steamed Bolu. 2018.

[5] Hearsa AA, Elida. Analisis Kualitas Kulit Pie Dengan Substitusi. J Kapita Sel Geogr 2019;2:7-14.

[6] Gunawan L. Hypertension High Blood Pressure. 2007. RI K Profile Kesehatan Indonesia Tahun 2017. Ministry Of Health Indonesia. 2018.

[7] Teknologi J, Pertanian H, Pertanian F, Kuala US. Pengaruh Suhu Dan Lama Pengeringan Terhadap Kuantitas Dan Kualitas Pati Kentang Varietas Granola. Pengaruh Suhu Dan Lama Pengeringan Terhadap Kuantitas Dan Kualitas Pati Kentang Var Granola 2012;4:26-30. Https://Doi.Org/10.17969/Jtipi.V4i3.740.

[8] Mulyadi AF, Wijana S, Dewi IA, Putri WI. KARAKTERISTIK ORGANOLEPTIK PRODUK MIE KERING UBI JALAR KUNING ( Ipomoea Batatas ) ( KAJIAN PENAMBAHAN TELUR DAN CMC) Organoleptic Characteristics Of Dry Noodle Products From Yellow Sweet Potato ( Ipomoea Batatas ) ( Study On Adding Eggs And CMC ). J Teknol Pertan 2014;15:25-36.

[9] Handayani F., Elida. Differences In Pie Skin Quality With Rub In And Bleding (Creaming) Stirring Methods. Home Econ Tour 2018; Vol. 18 No.

[10] Nojiri K, Kobayashi S, Higurashi S, Takahashi T, Tsujimori Y, Ueno HM, Et Al. Maternal Health And Nutrition Status, Human Milk Composition, And Growth And Development Of Infants And Children: A Prospective Japanese Human Milk Study Protocol. Int J Environ Res Public Health 2020;17:1-10. Https://Doi.Org/10.3390/Ijerph17061869.

[11] Ladamay NA, Yuwono SS. Pemanfaatan Bahan Lokal Dalam Pembuatan Foodbars (Kajian Rasio Tapioka: Tepung Kacang Hijau Dan Proporsi CMC). J Pangan Dan Agroindustri 2014;2:67-78.

[12] Winarno F. Food Chemistry And Nutrition. 2004.

[13] Ratnasari D, Yunianta. Pengaruh Tepung Kacang Hijau, Tepung Labu Kuning, Margarin Terhadap Fisikokima Dan Organoleptik Biskuit. Pangan Dan Agroindustri 2015;3:165261.

[14] Rasmaniar, Ahmad, Balaka S. Proximate And Organoleptic Analysis Of Biscuits From Yellow Sweet Potato Flour (Ipomea Betatas), Green Beans Flour And Seaweed Flour As Healthy Breakfast For School Children. J Food Sci Technol 2017;Vol. 2 No.

[15] Erlinawati I, Wiwik I, Hendriyani H. The Effect Of Green Been Flour Subtitution (Vigna Radiata) On Nutritional Value (Fiber And Carbohydrate) And Cookies Acceptability Of Purple Sweet Potato Flour (Ipomea Betatas L0. J Poltekkes Semarang N.D.

[16] Salsabila R. Analysis Of The Aplication Of Dictary Approaches To Stop Hypertension (DASH) In Patients With Hypertension. N.D.

[17] Rahman AM. Studying The Chemical And Physical Characteristics Of Tapioca And Mocal Flour (Modified Cassava Flour) As A Coating For Peanuts In Coated Peanut Products. 2007 